\title{
Magnitude of Obesity/Overweight and Its Associated Factors Among HIVI AIDS Patients on Antiretroviral Therapy in Jimma Zone Hospitals, SouthWest Ethiopia: Hospital-Based Cross-Sectional Study [Corrigendum]
}

Yitbarek GY, Engidaw MT, Ayele BA, Tiruneh SA, Alamir MT. Diabetes Metab Syndr Obes. 2020;13:1251 -1258.

The authors have advised that there is an error with the AOR of the independent variable physical activity throughout the paper.

Page 1251, Abstract, Results, line 4, the text "presence of mild to moderate physical activity $[\mathrm{AOR}=1.3,95 \% \mathrm{CI}(5.5,33.3)$, $\mathrm{p} \leq 0.001)$ ]" should read "absence of mild to moderate physical activity $[\mathrm{AOR}=6.3,95 \% \mathrm{CI}(5.5,33.3), \mathrm{p} \leq 0.001)]$ '.
Page 1254, left column, line 3 from the bottom, the text "presence of mild to moderate physical activity [AOR = $1.3,95 \%$ CI $(5.5,33.3), \mathrm{p} \leq 0.001)]$ " should read "absence of mild to moderate physical activity $[\mathrm{AOR}=6.3,95 \% \mathrm{CI}$ $(5.5,33.3), \mathrm{p} \leq 0.001)]^{\prime}$.

Page 1255, Table 3, AOR (95\% CI) column, the data for AOR "1.3" should read "6.3" in the variable Physical Activity, No row.

The authors apologize for these errors.

\section{Publish your work in this journal}

Diabetes, Metabolic Syndrome and Obesity: Targets and Therapy is an international, peer-reviewed open-access journal committed to the rapid publication of the latest laboratory and clinical findings in the fields of diabetes, metabolic syndrome and obesity research. Original research, review, case reports, hypothesis formation, expert opinion and commentaries are all considered for publication. The manuscript management system is completely online and includes a very quick and fair peer-review system, which is all easy to use. Visit http://www.dovepress.com/testimonials.php to read real quotes from published authors. 